\title{
Wastewater reuse in Kuwait: opportunities and constraints
}

\author{
A. Abusam \& A. B. Shahalam \\ Water Research Center, Innovative Technologies for Water Treatment \\ and Reclamation Program, Kuwait Institute for Scientific Research, \\ Kuwait
}

\begin{abstract}
Availability of adequate water resources is a fundamental requirement for sustainable development. Because of its very limited amounts of freshwater resources, Kuwait has depended on the expensive desalination of seawater for many years to satisfy almost all of its water demands. In order to cope with its water scarcity problems, over the last two decades, Kuwait has vigorously implemented a plan to reuse treated municipal wastewater. This paper assesses the qualities of municipal and industrial wastewater in Kuwait, and focuses on the main opportunities and constraints to wastewater reclamation and reuse in Kuwait. The paper also provides recommendations that will help surmount the constraints.
\end{abstract}

Keywords: wastewater, reclamation, reuse, opportunities, constraints, sustainability.

\section{Introduction}

Wastewater reuse has proven to be economically feasible and environmentally acceptable. Recycling treated wastewater is now a common practice, especially in arid and semiarid regions where water resources are very limited [1]. For water-scarce areas, wastewater reuse represents a reliable and steady supply of water throughout the year [2]. In addition, wastewater reuse brings numerous economical and environmental benefits that include reduction of freshwater extraction from the environment, enhancement of crop productivity and reduction of environmental degradation [1, 3]. 
Kuwait is situated in a harsh environment characterized by little rainfall (130 $\mathrm{mm} / \mathrm{yr}$ ) and high evaporation rates (400 mm/yr). It has no natural freshwater resources other than very limited amounts of brackish groundwater, which are depleting quickly. Thus, Kuwait has to rely on the costly seawater desalination process to meet its water demand, which is growing rapidly due to population growth and urbanization. To maintain its sustainable development, Kuwait has recently adopted a vigorous campaign to reuse treated municipal wastewater mainly as a source of irrigation water [4].

This paper assesses the quality of municipal and industrial wastewaters generated in Kuwait, and explores opportunities for reuse. It also highlights the main constraints to wastewater reuse in Kuwait and recommends measures to alleviate them.

\section{Wastewater management in Kuwait}

Municipal wastewater in Kuwait is treated at four main treatment plants located in Jahra, Riqqa, Sulaibiya and Umm Al-Haiman. At the present time, Kuwait generates about $800,000 \mathrm{~m}^{3}$ of municipal wastewater daily, about $60 \%$ $\left(>425,000 \mathrm{~m}^{3} / \mathrm{d}\right.$ ) of which is treated to advanced levels using ultrafiltration (UF) through reverse osmosis (RO) membranes at the Sulaibiya plant. The other three plants altogether treat about $375,000 \mathrm{~m}^{3} / \mathrm{d}$ to a tertiary level using sand filtration and chlorination. Most of the treated wastewater is pumped to storage reservoirs, with a combined capacity of $38,000 \mathrm{~m}^{3}$, at the Data Monitoring Center (DMC). There is a distribution network that connects the DMC with the main farming areas in Sulaibiya, Abdali and Wafra. The DMC monitors the supply of treated wastewater to these farming areas.

In contrast to municipal wastewater, industrial wastewater is poorly managed in Kuwait. There are now more than 5000 industrial firms in Kuwait. Most of these industries are located mainly in Shuaiba, Mina Abdullah and Mina Al-Ahmadi [5]. Major part of the wastewater from these industries is dumped in the sea or desert $[6,7]$.

\section{Materials and methods}

Influent and effluent municipal wastewater samples were collected from the four main treatment plants in Kuwait. The quality of the collected wastewater samples was determined at the laboratories of Suliabiya Research Plant (SRP) of the Kuwait Institute for Scientific Research (KISR) according to standard methods [8]. The water quality parameters that were determined were hydrogen ion concentration $(\mathrm{pH})$, biochemical oxygen demand $\left(\mathrm{BOD}_{5}\right)$, chemical oxygen demand (COD), oil and grease (O\&G), total suspended solids (TSS), total dissolved solids (TDS), ammonia nitrogen $\left(\mathrm{NH}_{4}-\mathrm{N}\right)$, total Kjeldah nitrogen $(\mathrm{TKN})$, total phosphate (TP), fluorides $(\mathrm{Fl})$, hydrogen sulfide $\left(\mathrm{H}_{2} \mathrm{~S}\right)$, residual chlorine, (Res $\left.\mathrm{Cl}_{2}\right)$, aluminium, $(\mathrm{Al})$, arsenic $(\mathrm{Ar})$, barium $(\mathrm{Ba})$, boron $(\mathrm{B})$, cadmium $(\mathrm{Cd})$, cobalt $(\mathrm{Co})$, copper $(\mathrm{Cu})$, iron $(\mathrm{Fe})$, lead, $(\mathrm{Pb})$, manganese $(\mathrm{Mn})$, 
mercury (Hg), nickel (Ni), zinc ( $\mathrm{Zn})$, and total coliform, fecal coliform, salmonella and coliphage.

The suitability of the municipal effluents for agricultural reuse was then assessed using the standards of the Kuwait Environment Public Authority (KEPA) (Table 1).

Table 1: $\quad$ KEPA standard for treated sewage for reuse in irrigation [9].

\begin{tabular}{|c|c|c|c|}
\hline Parameter & Standard & Parameter & Standard \\
\hline $\mathrm{pH}(-)$ & $6.5-8.5$ & $\mathrm{Ar}(\mathrm{mg} / 1)$ & 0.1 \\
\hline $\mathrm{BOD}_{5}(\mathrm{mg} / \mathrm{1})$ & 20 & $\mathrm{Ba}(\mathrm{mg} / 1)$ & 2 \\
\hline COD (mg/1) & 100 & $\mathrm{~B}(\mathrm{mg} / \mathrm{1})$ & 2 \\
\hline O\&G (mg/1) & 5 & $\mathrm{Cd}(\mathrm{mg} / 1)$ & 0.01 \\
\hline TSS (mg/1) & 15 & Co (mg/1) & 0.2 \\
\hline TDS (mg/1) & 1500 & $\mathrm{Cu}(\mathrm{mg} / 1)$ & 0.2 \\
\hline $\mathrm{NH}_{4}-\mathrm{N}(\mathrm{mg} / 1)$ & 15 & $\mathrm{Fe}(\mathrm{mg} / 1)$ & 5 \\
\hline TKN (mg/1) & 35 & $\mathrm{~Pb}(\mathrm{mg} / 1)$ & 0.5 \\
\hline TP (mg/1) & 30 & $\mathrm{Mn}(\mathrm{mg} / 1)$ & 0.2 \\
\hline Phenol (mg/l) & 1 & $\mathrm{Hg}(\mathrm{mg} / 1)$ & 0.002 \\
\hline $\mathrm{Fl}(\mathrm{mg} / 1)$ & 25 & $\mathrm{Ni}(\mathrm{mg} / 1)$ & 0.2 \\
\hline Sulfide (mg/1) & 0.1 & Zn (mg/1) & 2.0 \\
\hline Res $\mathrm{Cl}_{2}(\mathrm{mg} / 1)$ & $0.5-1.0$ & $\begin{array}{l}\text { Total Coliform, } \\
\text { (MPN/100 ml) }\end{array}$ & 400 \\
\hline DO (mg/1) & $>2$ & $\begin{array}{l}\text { Fecal Coliform } \\
\text { (MPN/100 ml) }\end{array}$ & 20 \\
\hline Hydrocarbons (mg/1) & 5 & Egg Parasites (eggs/l) & $<1$ \\
\hline $\mathrm{Al}(\mathrm{mg} / 1)$ & 5 & $\begin{array}{c}\text { Worm Parasites } \\
(\text { eggs } / \mathrm{l})\end{array}$ & None \\
\hline
\end{tabular}

Table 2: $\quad$ KEPA’s standards for industrial discharge to sewers [9].

\begin{tabular}{|l|c|l|c|c|c|}
\hline \multicolumn{1}{|c|}{ Parameter } & Standard & Parameter & Standard & Parameter & Standard \\
\hline BOD $_{5}(\mathrm{mg} / \mathrm{l})$ & 500 & $\mathrm{CN}(\mathrm{mg} / \mathrm{l})$ & 0.1 & $\mathrm{H}_{2} \mathrm{~S}(\mathrm{mg} / \mathrm{l})$ & 10 \\
\hline $\mathrm{COD}(\mathrm{mg} / \mathrm{l})$ & 750 & $\mathrm{Cu}(\mathrm{mg} / \mathrm{l})$ & 0.5 & $\mathrm{Ar}(\mathrm{mg} / \mathrm{l})$ & 0.1 \\
\hline TSS $(\mathrm{mg} / \mathrm{l})$ & 300 & $\mathrm{~Pb}(\mathrm{mg} / \mathrm{l})$ & 0.5 & $\begin{array}{c}\text { Total Coliform, } \\
\text { MPN/100 ml }\end{array}$ & 1,000 \\
\hline EOG (mg/l) & 30 & $\mathrm{Hg}(\mathrm{mg} / \mathrm{l})$ & 0.002 & $\begin{array}{c}\text { Fecal Coli, } \\
\text { MPN/100 ml }\end{array}$ & 100 \\
\hline FOG (mg/l) & 20 & $\mathrm{~N}(\mathrm{mg} / \mathrm{l})$ & 0.2 & $\begin{array}{c}\text { Egg Parasite, } \\
\text { eggs/l }\end{array}$ & 0 \\
\hline Tar Oil (mg/l) & 0 & $\mathrm{Ag}(\mathrm{mg} / \mathrm{l})$ & 4 & & \\
\hline $\mathrm{SO}_{4}(\mathrm{mg} / \mathrm{l})$ & 1,000 & $\mathrm{Zn} \mathrm{(mg/l)}$ & 2 & & \\
\hline
\end{tabular}

In addition, raw industrial wastewater samples were collected from 36 industrial sites: 2 textile factories, 5 dairy factories, 9 slaughter, meat packing and poultry processing factories, 2 petroleum refineries, 3 organic and inorganic chemical factories, 2 laundry facilities, 3 bakery factories, 2 soft drink factories, 2 detergent factories, 2 metal manufacturing factories, 1 car wash facility, 1 petrochemical factory, 1 pesticide factory and 1 paper factory. The quality of the 
collected samples was also determined at KISR's SRP according to the standards of the American Public Health Association (APHA) [8]. Then, the suitability of the raw industrial wastewater for discharge into the public sewers or the sea was assessed using KEPA's standards (Tables 2 and 3).

Table 3: KEPA's maximum limits for industrial discharges to water bodies [9].

\begin{tabular}{|c|c|c|c|}
\hline Parameter & Standard & Parameter & Standard \\
\hline Color & Free of pollutants & Aluminium, mg/l & 5 \\
\hline $\mathrm{pH}$ & 6 to 8 & Arsenic, mg/l & 0.1 \\
\hline Temperature, ${ }^{\circ} \mathrm{C}$ & 10 & Barium, mg/l & 2 \\
\hline BOD, mg/l & 30 & Boron, mg/l & 0.75 \\
\hline COD, mg/l & 200 & Beryllium, mg/l & 0.1 \\
\hline Oil \& Grease, mg/l & 5 & Cadmium, mg/l & 0.01 \\
\hline TSS, mg/l & 10 & Cyanide, mg/l & 0.1 \\
\hline TDS, mg/l & 1,500 & Chromium, mg/l & 0.2 \\
\hline $\mathrm{PO}_{4}, \mathrm{mg} / \mathrm{l}$ & 2 & Nickel, mg/l & 0.2 \\
\hline $\mathrm{NH}_{4}, \mathrm{mg} / \mathrm{l}$ & 3 & Mercury, mg/l & 0.001 \\
\hline $\mathrm{NO}_{3}, \mathrm{mg} / \mathrm{l}$ & 30 & Cobalt, mg/l & 0.2 \\
\hline TKN, mg/l & 5 & Iron, mg/l & 5 \\
\hline Total N, mg/L & 30 & Antimony, mg/l & 1.0 \\
\hline Total Phenol, mg/l & 1 & Copper, mg/l & 0.2 \\
\hline Fluoride, mg/l & 25 & Manganese, mg/l & 0.2 \\
\hline Sulphur, mg/l & 0.5 & Zinc, mg/l & 2.0 \\
\hline Residual $\mathrm{Cl}_{2}, \mathrm{mg} / \mathrm{l}$ & 0.5 & Lead, mg/l & 0.5 \\
\hline $\mathrm{DO}, \mathrm{mg} / \mathrm{L}$ & $>2$ & Lithium, mg/l & 2.5 \\
\hline Turbidity, NTU & 30 & Molybdenum, mg/l & 0.01 \\
\hline Hydrocarbons, mg/l & 5 & Vanadium, mg/l & 0.1 \\
\hline Floatables, mg/l & none & Silver, mg/l & 0.1 \\
\hline $\begin{array}{l}\text { Total Coliform, } \\
\text { MPN/100 ml }\end{array}$ & 1,000 & Pesticides, mg/l & 0.2 \\
\hline
\end{tabular}




\section{Results and discussion}

\subsection{Municipal wastewaters}

Table 4 compares the average quality of the raw wastewaters treated at the four plants to the typical medium-strength raw wastewater cited by Metcalf and Eddy [10]. As can be seen from this table, the characteristics of the raw wastewater treated at these plants corresponds closely to the values for medium-strength raw wastewater, except for the high phosphorus concentrations found at the Riqqa and Sulaibiya treatment plants. Phosphorus usually enters wastewater from domestic or industrial activities; the use of phosphorus-rich detergents is the main source of phosphorus in domestic wastewater. In Kuwait, industries are not actually connected to the public sewerage system. Thus, illegal dumping of industrial wastewaters into the public sewers seems to be the cause of the high phosphorus levels in the influents of the municipal treatment plants, as was noticed by Ghobrial et al. [11].

Table 4: Quality of raw municipal wastewater treated at Kuwait's main wastewater treatment plants.

\begin{tabular}{|l|c|c|c|c|c|}
\hline \multicolumn{1}{|c|}{ Parameter } & Jahra & Riqqa & Sulaibiya & $\begin{array}{c}\text { Umm Al- } \\
\text { Haiman }\end{array}$ & $\begin{array}{c}\text { Medium } \\
\text { Strength } \\
\text { Waste-water }\end{array}$ \\
\hline COD & 351 & 368 & 456 & 436 & 430 \\
\hline TSS & 199 & 271 & 226 & 234 & 210 \\
\hline TN & 29 & 36 & 36 & 32 & 40 \\
\hline TP & 18 & 27 & 29 & 21 & 7 \\
\hline Total Coliform & $2.72 * 10^{7}$ & $2.71 * 10^{9}$ & $3.38^{*} 10^{7}$ & $4.45^{*} 10^{8}$ & $10^{7}-10^{9}$ \\
\hline Fecal Coliform & $8.19 * 10^{5}$ & $5.41^{*} 10^{7}$ & - & $4.05^{*} 10^{6}$ & $10^{6}-10^{8}$ \\
\hline
\end{tabular}

Comparison of the quality of the treated municipal wastewater to KEPA's standards (Table 5) indicates that the TSS, COD and $\mathrm{BOD}_{5}$ concentrations at the Sulaibiya plant (RO permeate) are superior to those of the tertiary effluents and far below KEPA recommended upper limits. However, the tertiary effluents also meet the KEPA's standards, except for total coliform, which is a bit high.

Table 5 also shows that RO advanced treatment greatly reduced total nitrogen (TN) and total phenol (TP) concentrations in the final product, making the treated wastewater unsuitable for agricultural irrigation due to its deficiency in nutrients. In contrast, the tertiary effluents are usually rich in nutrients. Another problem with RO treatment is the loss of significant amounts of water as brine. The RO brine stream is usually laden with concentrated nutrients, salts, and inorganic materials, and devoid of organic materials. Therefore, treatment, management and disposal of RO brine poses a great challenge [12]. At the Sulaibiya plant, the brine stream is diluted with effluent and discharged into the sea. Table 6 shows that water losses at tertiary plants is negligible (1-4\%), while it is more than $40 \%$ for the RO plant at Sulaibiya. Obviously, the loss of such huge amounts of water cannot be justified. Thus, we recommend that the RO 
Table 5: Comparison of the qualities of tertiary- and advanced-treated effluents in Kuwait in 2005.

\begin{tabular}{|l|c|c|c|c|c|}
\hline & \multicolumn{3}{|c|}{ Parameter } & \multicolumn{3}{|c|}{} & $\begin{array}{c}\text { Advanced } \\
\text { Treatment } \\
\text { Plant }\end{array}$ & KEPA \\
Standard \\
\cline { 2 - 5 } & Riqqa & Jahra & $\begin{array}{l}\text { Umm Al- } \\
\text { Haiman }\end{array}$ & Sulaibiya & \\
\hline TSS (mg/l) & 4.7 & 5.9 & 3.7 & 2.95 & 15 \\
\hline COD (mg/l) & 13.8 & 23.9 & 12.5 & 3.1 & 100 \\
\hline BOD $(\mathrm{mg} / \mathrm{l})$ & 1.8 & 14.0 & 3.5 & 1.3 & 20 \\
\hline TN (mg/l) & 10.4 & 4.3 & 9.0 & 1.6 & 35 \\
\hline TP (mg/l) & 27.17 & 2.4 & 50.8 & 2.29 & 30 \\
\hline $\begin{array}{l}\text { Total } \\
\text { Coliform }\end{array}$ & 2170 & 9690 & 14464 & 1.0 & 400 \\
\hline $\begin{array}{l}\text { Fecal } \\
\text { Coliform }\end{array}$ & 15.8 & 1.1 & 1.4 & - & 20 \\
\hline
\end{tabular}

Table 6: Comparison of the amount of water lost during treatment at Kuwait's main municipal WWTPs in 2005.

\begin{tabular}{|l|c|c|c|c|}
\hline \multirow{2}{*}{ Parameter } & \multicolumn{3}{|c|}{ Tertiary Treatment Plants } & $\begin{array}{c}\text { Advanced Treatment } \\
\text { Plants }\end{array}$ \\
\cline { 2 - 5 } & Riqqa & Jahra & $\begin{array}{c}\text { Umm Al- } \\
\text { Haiman }\end{array}$ & Sulaibiya \\
\hline $\begin{array}{l}\text { Influent } \\
\left(\mathrm{m}^{3} / \mathrm{d}\right)\end{array}$ & 132691 & 68455 & 10694 & 340497 \\
\hline $\begin{array}{l}\mathrm{Effluent} \\
\left(\mathrm{m}^{3} / \mathrm{d}\right)\end{array}$ & 131969 & 67600 & 10302 & 207245 \\
\hline $\begin{array}{l}\text { Water Lost } \\
(\%)\end{array}$ & 0.54 & 1.24 & 3.67 & 39.13 \\
\hline
\end{tabular}

units be bypassed or at least that the amounts of wastewater treated to the RO level be limited to the actual demand for such high-quality water.

As demonstrated, the quality of the treated municipal wastewater in Kuwait is very good, and is thus suitable for many reuse applications other than agricultural irrigation. To maximize the benefits of wastewater reuse, the country needs to diversify the applications for which such water is used. Other applications such as urban domestic supply (e.g., toilet flushing, vehicle washing, and fire protection), industrial supply (e.g., cooling water and boiler feedwater), environmental supply (e.g., irrigation of golf courses, hunting and equestrian clubs), and artificial recharge of groundwater should be encouraged. In fact, artificial recharge is still at the experimental stage, and also there are very few environmental reuse applications of treated wastewater in Kuwait. Further, industrial reuse of wastewater is applied by only a few factories. 
Furthermore, despite the fact that $85 \%$ of the domestic wastewater in Kuwait is grey water which can easily be recycled or reused [13], there are not any demonstration project for urban applications of grey water.

In fact, several technical, social-economic and cultural factors constrict grey water reuse in Kuwait. For example, there are no quality guidelines or standards for grey-water reuse. Also, the existing plumbing system is a single system and changing to a dual system would require financial support as it is expensive. However, the main problem is of a cultural or religious nature. Many do not accept grey water even though Islam allows the reuse of wastewater if it is adequately treated for the intended use [14]. This constraint could be overcome by educating the people and gaining their trust in the quality of the treated wastewater.

\subsection{Industrial wastewaters}

Tables 7, 8 and 9 show that multiple quality parameters of wastewater from most of the sampled industries exceed KEPA's standards for discharge into public sewers (Table 2). This means that the studied industrial wastewaters need appropriate treatment before they can be discharged into the public sewers. Furthermore, Table 3 indicates that some of these industries produce phosphateand nitrogen-laden wastewaters, which are not fit for discharge into the sea. Nevertheless, some industries regularly discharge their industrial wastewater into the sea [6].

Also huge amounts of water are co-produced during oil production (7 barrel/barrel). At present, Kuwait produces about 3.5 million barrels of oil a day, and has plans to produce 4 million barrels per day by 2030. The production rate of produced water is actually steadily increasing due to the increased oil production and the ageing of oil fields [15]. Similar to other industrial wastewater, produced water is not managed properly. It is usually disposed of into unlined seepage pits and left to evaporate. Due to numerous environmental problems encountered, however, disposal to sealed pits and underground injection were introduced of late [7]. Generally, produced water is not utilized beneficially and also there is no reliable information on its quality.

In order to protect the environment and have more alternative water for reuse, implementation of KEPA's regulations is urgently needed. All types of industrial wastewaters should be treated appropriately. They should be considered as an alternative water resource that can be utilized beneficially to augment the already scarce water available. Depending on their characteristics, industrial wastewaters that meet KEPA's standards can be treated off-site at municipal wastewater treatment plants, while those that do not can be treated on-site or at special treatment plants. Also, regulations for industrial wastewater should be based on the type of industry rather than having a blanket regulation that is applicable to all industries. Furthermore, the regulations should include standards for important parameters such as alkalinity, acidity, phenols, pesticides, salinity, dissolved oxygen (DO), boron, surfactants etc. 
752 The Sustainable City VIII, Vol. 2

\begin{tabular}{|c|c|c|c|c|c|c|c|c|c|c|c|c|c|c|c|c|c|}
\hline $\begin{array}{l}\text { ज्ञ } \\
3 \\
3 \\
\text { जే }\end{array}$ & $\infty$ & 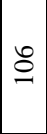 & $\stackrel{2}{R}$ & ' & $\hat{\circ}$ & $\stackrel{\mathscr{V}}{\underset{\sim}{\sim}}$ & $\stackrel{\widetilde{Z}}{\underset{\sim}{*}}$ & ' & ' & 1 & ' & $\stackrel{\sim}{\sim}$ & ' & ' & $\stackrel{\mathcal{N}}{\mathcal{Z}}$ & ' & $\stackrel{N}{ }$ \\
\hline$\sum_{\Sigma}^{\frac{\pi}{2}}$ & $\sigma$ & $\mathscr{\infty}$ & 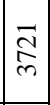 & $\stackrel{?}{ }$ & ิิ & $\hat{\theta}$ & 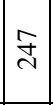 & $\sigma$ & $\exists$ & 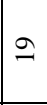 & $\nabla$ & 0 & ' & $\stackrel{\sim}{\sim}$ & 0 & $\sim$ & गे \\
\hline 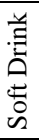 & $\infty$ & $\infty$ & 守 & 昰 & $\begin{array}{l}\mathscr{2} \\
0 \\
0\end{array}$ & タ & $\hat{\widehat{m}}$ & ' & $\curvearrowright$ & $\vec{\sim}$ & $\sim$ & ' & ' & $\stackrel{m}{\stackrel{m}{m}}$ & $\stackrel{2}{\sim}$ & $m$ & $\ddot{m}$ \\
\hline 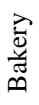 & L & $\begin{array}{l}\hat{\tilde{ల}} \\
\underline{-1}\end{array}$ & 1 & $\begin{array}{l}\tilde{W} \\
\text { N }\end{array}$ & $\begin{array}{l}\vec{N} \\
\text { న }\end{array}$ & 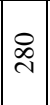 & 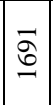 & ' & $\approx$ & $\vec{\sim}$ & $\sigma$ & F্ & ' & & 只 & $\stackrel{m}{\sim}$ & ले \\
\hline 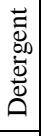 & $\curvearrowright$ & 느 & 1 & 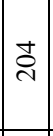 & 点 & $\stackrel{\Omega}{\simeq}$ & \& & ' & 号 & ชै & in & ' & is & 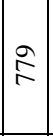 & ' & ' & $\stackrel{\infty}{\sim}$ \\
\hline $\begin{array}{l}\text { 롱 } \\
\text { 空 } \\
\end{array}$ & $\stackrel{ }{-1}$ & ৪ & $\hat{m}$ & $\begin{array}{l}\mathscr{m} \\
\mathscr{\infty}\end{array}$ & $\stackrel{0}{\sim}$ & $m$ & ' & ' & Ln & 1 & in & $-r$ & ' & ' & ' & ' & 贵 \\
\hline 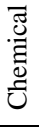 & $\sigma$ & $\vec{J}$ & 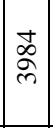 & 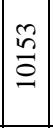 & $\begin{array}{l}0 \\
\stackrel{0}{\sim} \\
\sim\end{array}$ & $\tilde{m}$ & \begin{tabular}{|l|}
0 \\
0 \\
$\infty$
\end{tabular} & 0 & o & 0 & 0 & ' & ' & $\begin{array}{l}\stackrel{ \pm}{\tilde{m}} \\
\tilde{m}\end{array}$ & 0 & 0 & p \\
\hline 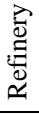 & $\infty$ & भु & ర్రి & 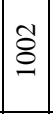 & 空 & 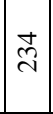 & 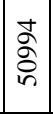 & $\approx$ & 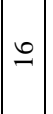 & 点 & 0 & $\nabla$ & $\nabla$ & 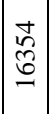 & n & $\begin{array}{l}\text { D } \\
\text { Oo } \\
\text { in }\end{array}$ & $\stackrel{\sim}{\sim}$ \\
\hline$\stackrel{\vec{J}}{\Sigma}^{\mathbb{d}}$ & $\wedge$ & 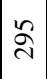 & $\begin{array}{l}\stackrel{O}{0} \\
\stackrel{0}{v}\end{array}$ & $\widetilde{\curvearrowright}$ & 导 & \& & ले & $\infty$ & 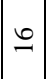 & $\approx$ & $\stackrel{\Delta}{\sim}$ & ' & $\curvearrowright$ & & $\infty$ & $\exists$ & 尝 \\
\hline 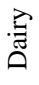 & $\wedge$ & ป & ' & \begin{tabular}{|l|}
$\mid$ \\
$\varnothing$ \\
$\varnothing$
\end{tabular} & $\begin{array}{l}\infty \\
\hat{N} \\
\hat{N}\end{array}$ & 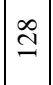 & $\underset{\sim}{\stackrel{2}{\sigma}}$ & 9 & $\approx$ & הี & $\approx$ & $\sim$ & ' & $\overrightarrow{6}$ & $\stackrel{\theta}{-1}$ & $\vec{\lambda}$ & $\widehat{\curvearrowright}$ \\
\hline 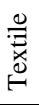 & $\sigma$ & $\stackrel{\infty}{\circ}$ & 命 & 品 & రి & กิ & ' & ' & $\nabla$ & 10 & -1 & ' & ' & ' & ' & ' & 尝 \\
\hline 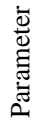 & 焉 & $\begin{array}{l}\infty \\
\omega \\
H\end{array}$ & 总 & 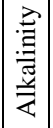 & Oิ & Oి & $\vec{v}$ & 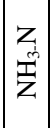 & $\mid \begin{array}{l}z \\
y \\
z\end{array}$ & Z & $\stackrel{\infty}{ }^{+}$ & 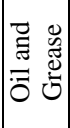 & is & $\ddot{z}$ & U & $\sum_{\Sigma}^{\infty}$ & 节 \\
\hline
\end{tabular}


Table 8: Heavy metals concentrations of industrial wastewaters in Kuwait.

\begin{tabular}{|l|c|c|c|}
\hline Parameter & Refinery & Chemical & Metal \\
\hline $\mathrm{Hg}$ & - & - & 0.001 \\
\hline $\mathrm{Zn}$ & - & 0.1 & 0.25 \\
\hline $\mathrm{Cu}$ & - & 0.0 & 0.01 \\
\hline $\mathrm{Fe}$ & - & 0.1 & 0.05 \\
\hline $\mathrm{Ni}$ & - & - & 0.11 \\
\hline $\mathrm{Cr}$ & 0.0 & - & - \\
\hline $\mathrm{Ag}$ & - & - & 0.2 \\
\hline $\mathrm{Cd}$ & 0.4 & 0.0 & 0.1 \\
\hline $\mathrm{Pb}$ & 0.1 & 0.0 & 0.04 \\
\hline $\mathrm{Cn}$ & 0.1 & 0.1 & 0.33 \\
\hline $\mathrm{As}$ & - & - & - \\
\hline $\mathrm{B}$ & 16.5 & 0.5 & 9.8 \\
\hline
\end{tabular}

Table 9: Biological quality of industrial wastewaters in Kuwait.

\begin{tabular}{|l|c|c|c|c|}
\hline \multicolumn{1}{|c|}{ Parameter } & Dairy & Meat & Laundry & Bakery \\
\hline $\begin{array}{l}\text { Total Coliform } \\
\text { Bacteria }\end{array}$ & 23741 & 744 & 608 & 8873 \\
\hline $\begin{array}{l}\text { Fecal Coliform } \\
\text { Bacteria }\end{array}$ & 106 & 104 & 1 & - \\
\hline Salmonella & 103 & 44 & 0 & 0 \\
\hline Coliphage Virus & 2 & 31 & 52 & 12 \\
\hline
\end{tabular}

\section{Conclusions and recommendations}

The following conclusions and recommendations were drawn from the assessment of municipal and industrial wastewater in Kuwait.

- $\quad$ The treated municipal wastewater is of a good quality and could be utilized beneficially in many applications other than agricultural irrigation. Wastewater reuse in the country needs to diversify, and the technical and socioeconomic constraints, particularly for urban reuse, need to be alleviated.

- There are huge amounts of industrial wastewater which are not being managed properly. After appropriate treatment, these wastewaters can be used to supplement the country's already limited water resources.

- The RO units in the Sulaibiya wastewater treatment plant should be bypassed entirely, or only used to treat limited amounts of wastewater that meet the actual demand for such high-quality effluent.

- Kuwait's existing wastewater reuse standards need to be refined in order to encourage treatment and reuse of industrial wastewater.

\section{Acknowledgement}

The data used in this study were collected during the execution of Project WT013C at the Kuwait Institute for Scientific Research entitled "Development 
of Wastewater Quality Database and Assessment of Effluent Quality for Potential Reuse in Kuwait”. This project was partially financed by the Kuwait Foundation for the Advancement of Sciences.

\section{References}

[1] Layson, A., and Sorgini, L., Low-pressure membranes help solve water scarcity, Water, Australian Water Association 34(7), pp. 34-36, 2007.

[2] Schaefer, M., Water technologies and environment - ramping up by scaling down. Technology in Society 30(3-4), pp. 415-422, 2008.

[3] Chakbarti, C., Residual effect of long-term land application of domestic wastewater. Environment International 21(3), pp. 333-339.

[4] Al-Shammari, S., and Shahalam, A.M., Water demand and wastewater management in Kuwait. Proc. of the $7^{\text {th }}$ Water Conference on Water in the GCC:- Towards an Integrated Management, (WASTA), Kuwait, pp. 701709, 2005.

[5] Ministry of Planning, Statistics and IT Sector, Annual Statistical Abstract, Edition 39, Kuwait, 2002.

[6] Al-Shati, I., Towards the use of industrial wastewater for irrigation in Kuwait. Desalination 72(1-2), pp. 115-124, 1989.

[7] Al-Hubail, J., and El-Dash, K., Managing disposal of water produced with petroleum in Kuwait. Journal of Environmental Management 79(1), pp. 4350, 2006.

[8] APHA, Standard methods for examination of water and wastewater, $21^{\text {st }}$ ed., American Public Health Association, Washington DC, USA, 2005.

[9] KEPA. Proposed Wastewater Reuse Standards, Kuwait Environment Public Authority (KEPA), Kuwait Al-Youm (newspaper), Annex to Issue 533, Year 47, 2001.

[10] Metcalf and Eddy, Wastewater Engineering Treatment, Disposal, Reuse, $3^{\text {rd }}$ ed., McGraw-Hill Publishing Company, Ltd., New York, 2003.

[11] Ghobrial, F., Lionel, M., Patel, B., and Awad, A., Assessment of raw sewage and treated effluents characteristics in Kuwait, Kuwait Institute for Scientific Research, Report No. KISR 2468, Kuwait, 1987.

[12] Abu-Gharah, Z.H., and Sherrad, J.H., Biological nutrient removal in high salinity wastewater, Journal of Environmental Science Health Part A 28(3), pp. 599-613, 1993.

[13] Abusam A., Reuse of greywater in Kuwait, International Journal of Environmental Studies 65(1), pp. 103-108, 2008.

[14] Faruqui N.I., Biswas, A.K., and Bino, M.J., Water Management in Islam, IDRC and UN, University Press, Ottawa, Canada, 2001.

[15] Al-Anezi, K., Belkharchouche, M., Alali, S., and Abuhaimed, W., Produced water characterization in Kuwait and its impact on environment. Desalination and Water Treatment, 51(1-3), pp. 302-306, 2013. 